\title{
A Structural Relationship Between Domestic Tourist Satisfaction, Trust, Switching Barriers And Retention
}

Aurathai Lertwannawit, Thammasat University, Thailand Nak Gulid, Srinakharinwirot University, Thailand

\begin{abstract}
The objective of this study is to examine the direct effects of satisfaction, trust, and switching barriers on customer retention in Bangkok and Pattaya, Chonburi province. Four hundred and forty questionnaires were distributed as the means of data collection and analyzed using structural equation modeling (SEM). The results of testing hypotheses are as follows:

1. The developed structural equation model of customer retention in Bangkok was congruent with empirical data as the criterion, as follows: $\left(\chi^{2}=141.098, d f=69, \chi^{2} / d f=\right.$ 2.045, GFI $=.956, A G F I=.933, R M S E A=.049, R M R=.073, C F I=.979)$. Factors influencing customer retention in Bangkok included the following: a) satisfaction showed the highest level of direct influence $=.225$ and $b$ ) switching barriers with direct influence $=.193$, followed by trust $=.188$ with statistical significance at the .001 level.

2. The developed structural equation model of customer retention in Pattaya was congruent with empirical data as the criterion, as follows: $\left(\chi^{2}=95.438, d f=49, \chi^{2} / d f=1.948, G F I\right.$ $=.966, A G F I=.945, R M S E A=.046, R M R=.077, C F I=.982)$. Factors influencing customer retention in Pattaya included the following: a) switching barriers showed the highest level of direct influence $=.251$ and $b$ ) trust with direct influence $=.240$, followed by satisfaction $=.159$ with statistical significance at the .001 level.
\end{abstract}

Keywords: Satisfaction; Trust; Switching Barriers; Retention

\section{INTRODUCTION}

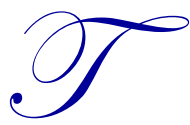

he tourism industry is the most important industry in Thailand; it created the greatest amount of revenue in 2012. The revenue from the tourism industry that year was THB965,000 million. The Tourism Ministry Council announced in 2011 that tourism industry revenue should increase by twice within 5 years (The Secretariat of the Cabinet, 2011). The tourism industry is not only supported by the government sector, but also by private media. For example, Travel and Leisure Magazine has reported that American tourists have voted Bangkok the World's Best City Award for three consecutive years. Forbes magazine has reported that Bangkok is the best city in the world for street food (Bender, 2012). Pattaya, Chonburi Province has many seaside attractions and has also brought significant revenue to Thailand. However, as the world economy (particularly in the US and Europe) remains in recession, the Thai government has started a campaign to increase and support domestic tourism.

Satisfaction is the most important factor driving customer retention (Oliver, 1980; Yi, 1990). If the tourism industry at each destination increases satisfaction, customers will create positive word-of-mouth and increase the revenue to the destination (Fornell et al., 1995). To retain customers, satisfaction is not the only important factor driving customer loyalty. Also included are trust and switching barriers, especially in the tourism industry. The conceptual framework model in this study was derived from Ranaweera and Prabhu (2003). Structural equation modeling, however, is employed to analyze factors influencing customer retention instead of regression analysis. 
The tested hypotheses will be evaluated from a survey of domestic tourists who traveled to both Bangkok and Pattaya. These destinations attract the highest number of visitors compared to other locations (www.tourism. go.th). The results of this research are the first steps to develop policy and strategy at each destination to enhance revenue and employment in the tourism industry.

\section{CONCEPTUAL FRAMEWORK AND HYPOTHESES}

The objective of this research is to study direct effects on customer retention (Thai tourists) at both destinations. The proposed model is adapted from several research papers, including Ranaweera and Probhu, 2003, Liang and Wang, 2006, and Chadha and Kapoor, 2009. The proposed model is shown in Figure 1:

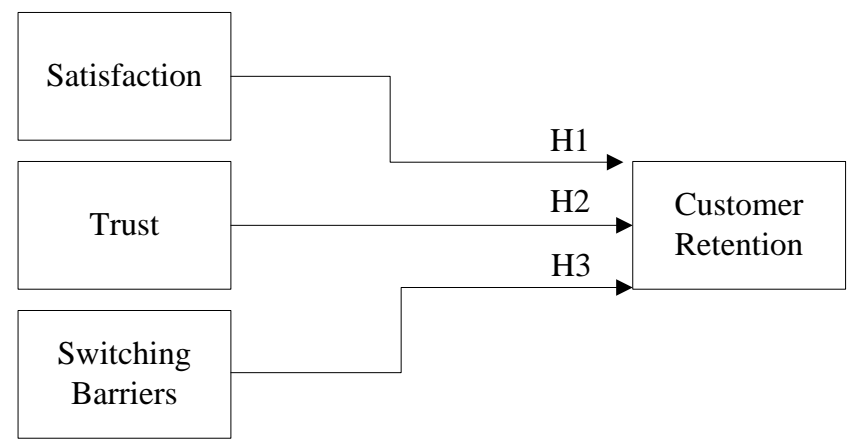

Figure 1: Conceptual Framework

\section{Customer Retention}

Protecting the existing customer base and retaining existing customer loyalty are crucial competitive advantages in the service sector. Developing and increasing customer loyalty strengthens the foundation of a firm's advantage and enhances its growth and performance (Lee and Cunningham, 2001; Gerpott et al., 2001). Customer retention is defined as "the future propensity of a customer to stay with the firm, brand or destination," (Ranaweera and Phabhu, 2003). Cronin et al. (2000, p.4) treat "behavioral intentions" and "customer retention" as synonymous constructions.

Customer satisfaction is the most important factor driving customer retention in a number of studies (Oliver, 1980; Yi, 1990; Chadha and Kapoor, 2009). However, satisfaction is not the only important determinant in driving customer retention. Trust and switching barriers also have direct impact on driving retention. The proposed model in this study examines the direct effects of satisfaction, trust, and switching barriers on customer retention in the tourism industry. These effects have rarely been examined. In several studies, satisfaction and trust are related, but they are conceptually different and have different effects on customer retention (Geyskens et al., 1998; Szymanski and Henand, 2001). Therefore, it is important to evaluate the effects of these two constructs. Switching barriers can help service firms reduce customer cost and retain customers, especially in the service sector. Thus, this research aims to study the direct effects of satisfaction, trust, and switching barriers on customer retention at both popular destinations.

\section{Satisfaction}

Customer satisfaction is defined as a "summary psychological state resulting when the emotion surrounding disconfirmed expectations is coupled with the customer's prior feelings about the consumption experience (Oliver, 1981, p.27)." Cronin et al. (2000) also defined customer satisfaction as an evaluation of an emotion, reflecting the degree to which the customer believes the firm, brand, or service providers stimulate positive feelings. After considerable research, a strong relationship has been found between satisfaction and customer retention, especially in the service sector (Cronin and Taylor, 1992; Patterson et al., 1997; Ranaweera and Phabhu, 2003). According to the above, we can hypothesize that: 
$\mathbf{H}_{1}$ : Satisfaction has a direct effect on customer retention.

\section{Trust}

The growth of relationship marketing has heightened interest in the role of trust in fostering strong relationships. Berry and Parasuraman (1991) stated that "relationship marketing concerns attracting, developing, and retaining customer relationships." In several studies, it has been shown that trust is a key determinant of relational commitment and the essential element in building strong customer relationships and sustainable market share (Spekman, 1988; Gundlach and Murphy, 1993; Garbarino and Johnson, 1999; Urban, Sultan et al., 2000). Hart and Johnson (1999) concluded that trust is another factor beyond customer satisfaction to retain customers for the long term. They also found that trust has greater impact on customer retention than satisfaction. Morgan and Hunt (1994) define trust as existing when one party has confidence in an exchange partner's reliability and integrity. According to the above, we can hypothesize that:

$\mathbf{H}_{2}$ : Trust has a direct effect on customer retention.

\section{Switching Barriers}

Switching barriers has a significant effect on customer retention in business-to-business and employer-toemployee relationships (Gremler and Brown, 1996; Bansal and Taylor, 1999; Lee et al., 2001). Switching barriers is defined as the customer's assessment of the resources and opportunities needed to perform the switching act, or alternatively, the constraints that prevent the switching act (Bansal and Taylor, 1999; Ranaweena and Phabhu, 2003). Switching costs can be defined as the costs (both monetary and non-monetary) involved in changing from one supplier to another (Heide and Weiss, 1995). Switching barriers is consumer specific and its nature varies depending upon the industry structure and product characteristic (Shy, 2002; Gummesson, 1995). Several studies have indicated that customers investing time, money and effort define switching costs. This, as a result, affects their perceptions of the difficulty of switching (Gremler and Brown, 1996; Bansal and Taylor, 1999; Lee et al., 2001). Bansal and Taylor, 1999, Lee et al., 2001 and Ranaweera and Phabhu (2003) have tested and determined the positive effects of switching barriers on customer retention. Hence, we can hypothesize that:

$\mathbf{H}_{3}$ : Switching barriers has a direct effect on customer retention.

\section{RESEARCH DESIGN AND METHODOLOGY}

This study employs quantitative methodology and uses survey techniques to collect data. The sample size is 440 Thai tourists, as tallied by the number of questionnaires distributed. Quota sampling was employed at both destinations, Bangkok and Pattaya. Therefore, 220 domestic tourists were interviewed at each site. Judgmental sampling was also used to interview tourists at the most popular sites in Bangkok, including shopping centers, temples, museums and entertainment venues. In Pattaya, the most popular locations include museums, temples, shopping, and beaches. Convenience sampling was employed in selecting the respondents at each attraction.

\section{Measurements}

All measurement items of each construct and its Cronbach alpha level are summarized in Table 1. The questionnaires were measured by employing a five-point Likert scale ranging from "Strongly Agree" (5) to "Strongly Disagree" (1). All measures achieved Cronbach alpha beyond the recommended level of 0.60 passing the minimum requirement (Hair, Bush and Oftinau, 2004: 397). 
Table 1: Reliability of Measurements Used in this Study

\begin{tabular}{|l|c|}
\hline Scales Items & Cronbach's Alpha \\
\hline Satisfaction towards Destinations & .885 \\
\hline$-\quad$ Bangkok & .840 \\
\hline$-\quad$ Pattaya & .890 \\
\hline Trust towards Destinations & .867 \\
\hline$-\quad$ Bangkok & \\
\hline$-\quad$ Pattaya & .820 \\
\hline Switching Barriers & .824 \\
\hline$-\quad$ Bangkok & \\
\hline$-\quad$ Pattaya & .874 \\
\hline Customer Retention towards Destinations & .838 \\
\hline$-\quad$ Bangkok & \\
\hline$-\quad$ Pattaya & \\
\hline
\end{tabular}

\section{ANALYSIS AND RESULTS}

\section{Respondent Profiles}

The researcher collected data by interviewing 440 Thai tourists. The results indicated that the majority of respondents were female $(61.1 \%)$ and $54.5 \%$ were between 25 and 34 years old. They were a) single $(65.7 \%)$ with bachelor degrees $(68.4 \%)$, b) employed in the private sector (56.6\%) with monthly incomes between THB 10,001$15,000(34.5 \%)$ and c) resident in Bangkok (53.2\%). The decision to travel by themselves was made by $45.5 \%$.

\section{Structural Equation Modeling (SEM)}

The hypothesized model and the competing model consisting of four variables are seen in Table 2. The hypothesized model is adapted from Ranaweera and Phabhu (2003). It includes all three independent variables (satisfaction, trust, and switching barriers) that have direct effects on the dependent variable (customer retention). The competing model is derived from Garbarino and Johnson, 1999 and Liang and Wang (2006), where trust is a mediating variable of the relationship between satisfaction and customer retention. The result of the comparison between the hypothesized and the competing models for destinations in Bangkok is shown in Table 2:

Table 2: Standardized Parameter Estimates And Model Fit Statistics Of The Hypothesized Model And The Competing Model For Bangkok

\begin{tabular}{|c|c|c|c|c|c|c|}
\hline \multirow[t]{2}{*}{ H: } & \multirow[t]{2}{*}{ From } & \multirow[t]{2}{*}{ To } & \multirow{2}{*}{$\begin{array}{c}\begin{array}{c}\text { Hypothesized } \\
\text { Model }\end{array} \\
\begin{array}{c}\text { Standardized } \\
\text { Estimate }\end{array} \\
\end{array}$} & \multicolumn{3}{|c|}{$\begin{array}{c}\text { Competing } \\
\text { Model }\end{array}$} \\
\hline & & & & t-value & $\begin{array}{c}\text { Standardized } \\
\text { Estimate }\end{array}$ & t-value \\
\hline $\mathrm{H}_{11}$ & $\begin{array}{l}\text { Satisfaction } \\
\text { towards } \\
\text { Destinations }\end{array}$ & $\begin{array}{l}\text { Customer } \\
\text { Retention }\end{array}$ & $0.225 * *$ & 2.958 & 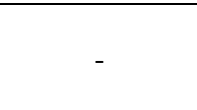 & - \\
\hline $\mathrm{H}_{21}$ & $\begin{array}{l}\text { Trust towards } \\
\text { Destinations }\end{array}$ & $\begin{array}{l}\text { Customer } \\
\text { Retention }\end{array}$ & $0.188 * * *$ & 3.848 & $.412 * * *$ & 7.633 \\
\hline $\mathrm{H}_{31}$ & $\begin{array}{c}\text { Switching } \\
\text { Barriers }\end{array}$ & $\begin{array}{l}\text { Customer } \\
\text { Retention }\end{array}$ & $0.193 *$ & 2.370 & $.179 * * *$ & 3.573 \\
\hline New Path & $\begin{array}{c}\text { Satisfaction } \\
\text { towards } \\
\text { Destinations }\end{array}$ & $\begin{array}{l}\text { Trust towards } \\
\text { Destinations }\end{array}$ & - & - & $1.000 * * *$ & 13.116 \\
\hline
\end{tabular}


(Table 2 continued)

\begin{tabular}{ccc}
\hline Model Goodness-of-fit Statistics & & 178.651 \\
\hline$\chi^{2}$ & 141.098 & 64 \\
\hline $\mathrm{df}$ & 69 & 2.791 \\
\hline$\chi^{2} / \mathrm{df}$ & 2.045 & 0.00 \\
\hline $\mathrm{p}-$ value & 0.00 & .946 \\
\hline GFI & .956 & .912 \\
\hline AGFI & .933 & .073 \\
\hline RMR & .073 & .064 \\
\hline RMSEA & .049 & 260.651 \\
\hline AIC & 213.098 & .967 \\
\hline CFI & .979 & .594 \\
\hline ECVI & .485 & 469.209 \\
\hline CAIC & 396.222 & .668 \\
\hline PNFI & .728 & .
\end{tabular}

Note: $*=0.05, * *=0.01, * * *=.001$ based one-tailed $\mathrm{t}$-values: $\mathrm{t}$-value $>1.65$ for $\mathrm{p}<0.05, \mathrm{t}$-value $>2.33$ for $\mathrm{p}<0.01$, $\mathrm{t}$-value $>$ 3.09 for $\mathrm{p}<0.001$ (Malhotra, 2004).

These two models are compared in terms of model parsimony and fit. Four measures (AIC, ECVI, CAIC, and PNFI) are used to compare the data. The criteria of the better fitted model and greater parsimony are decided by lower values of AIC, ECVI, CAIC along with the higher value of PNFI. The results from Table 2 indicate that all three values of AIC, ECVI, CAIC on the hypothesized model (AIC = 213.098, ECVI = .485, CAIC = 396.222) are lower than those of the competing model (AIC $=260.651$, ECVI $=.594$, CAIC $=469.209)$. The PNFI value of the hypothesized model $(\mathrm{PNFI}=.728)$ is higher than the PNFI value of the competing model $(\mathrm{PNFI}=.668)$. Therefore, the hypothesized model performs better fit and greater parsimony than the competing model.

The model explains $35.4 \%$ of the variance in customer retention. Satisfaction towards destinations performs the most important predictor $(\beta=.225)$, followed by switching barriers $(\beta=.193)$ and trust $(\beta=.188)$, all of which have significant positive direct effects on customer retention in Bangkok.

The results of the comparison between the hypothesized model and the competing model for destinations in Pattaya are shown in Table 3:

Table 3: Standardized Parameter Estimates And Model Fit Statistics

Of The Hypothesized Model And The Competing Model In Pattaya

\begin{tabular}{|c|c|c|c|c|c|c|}
\hline \multirow[t]{2}{*}{ H: } & \multirow[t]{2}{*}{ From } & \multirow[t]{2}{*}{ To } & \multirow{2}{*}{$\begin{array}{c}\text { Hypothesized } \\
\text { Model }\end{array}$} & \multicolumn{3}{|c|}{$\begin{array}{c}\text { Competing } \\
\text { Model }\end{array}$} \\
\hline & & & & t-value & $\begin{array}{c}\text { Standardized } \\
\text { Estimate }\end{array}$ & t-value \\
\hline $\mathrm{H}_{11}$ & $\begin{array}{c}\text { Satisfaction } \\
\text { towards } \\
\text { Destinations }\end{array}$ & $\begin{array}{l}\text { Customer } \\
\text { Retention }\end{array}$ & $0.159 *$ & 1.965 & 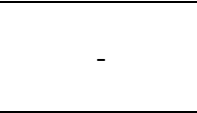 & - \\
\hline $\mathrm{H}_{21}$ & $\begin{array}{l}\text { Trust towards } \\
\text { Destinations }\end{array}$ & $\begin{array}{l}\text { Customer } \\
\text { Retention }\end{array}$ & $0.240 * *$ & 2.773 & $.368 * * *$ & 6.989 \\
\hline $\mathrm{H}_{31}$ & $\begin{array}{c}\text { Switching } \\
\text { Barriers }\end{array}$ & $\begin{array}{l}\text { Customer } \\
\text { Retention }\end{array}$ & $0.251 * * *$ & 5.028 & $.270 * * *$ & 5.599 \\
\hline New Path & $\begin{array}{c}\text { Satisfaction } \\
\text { towards } \\
\text { Destinations }\end{array}$ & $\begin{array}{c}\text { Trust towards } \\
\text { Destinations }\end{array}$ & - & - & $1.000 * * *$ & 12.748 \\
\hline
\end{tabular}


(Table 3 continued)

\begin{tabular}{ccc}
\hline Model Goodness-of-fit Statistics & & 127.869 \\
\hline$\chi^{2}$ & 95.438 & 49 \\
\hline $\mathrm{df}$ & 49 & 2.610 \\
\hline$\chi^{2} / \mathrm{df}$ & 1.948 & 0.00 \\
\hline $\mathrm{p}$-value & 0.00 & .951 \\
\hline GFI & .966 & .922 \\
\hline AGFI & .945 & .106 \\
\hline RMR & .077 & .061 \\
\hline RMSEA & .046 & 185.869 \\
\hline AIC & 153.438 & .969 \\
\hline CFI & .982 & .423 \\
\hline ECVI & .350 & 333.385 \\
\hline CAIC & 300.954 & .706 \\
\hline PNFI & .715 & 2.33 for
\end{tabular}

Note: $*=0.05, * *=0.01, * * *=.001$ based one-tailed $\mathrm{t}$-values: $\mathrm{t}$-value $>1.65$ for $\mathrm{p}<0.05, \mathrm{t}$-value $>2.33$ for $\mathrm{p}<0.01, \mathrm{t}$-value $>$ 3.09 for $\mathrm{p}<0.001$ (Malhotra, 2004).

These two models are compared in terms of model parsimony and fit. Four measures (AIC, ECVI, CAIC, and PNFI) are used to compare the data. The criteria of the better fitted model and greater parsimony are decided by lower values of AIC, ECVI, CAIC along with the higher value of PNFI. The results from Table 3 indicate that all three values of AIC, ECVI, CAIC on the hypothesized model $(\mathrm{AIC}=153.438, \mathrm{ECVI}=.350, \mathrm{CAIC}=300.954)$ are lower than those of the competing model $(\mathrm{AIC}=185.869, \mathrm{ECVI}=.423, \mathrm{CAIC}=333.385)$. The PNFI value of the hypothesized model (PNFI $=.715$ ) is higher than the PNFI value of the competing model (PNFI $=.706)$. Therefore, the hypothesized model performs better fit and greater parsimony than the competing model.

The model explains $30.6 \%$ of the variance in customer retention. Switching barriers performs the most important predictor $(\beta=.251)$, followed by trust $(\beta=.240)$, and satisfaction towards destinations $(\beta=.159)$, all of which have significant positive direct effect on customer retention in Pattaya.

\section{DISCUSSION AND IMPLICATION}

In this study, the results showed that all independent variables have strong impact on customer retention in both destinations. In addition, satisfaction has the strongest effect on customer retention in Bangkok, whereas switching barriers has the strongest impact on customer retention in Pattaya. This is consistent with the findings of Edward and Sahadev, 2011 and Raweera and Phabhu, 2003 which suggest that the service firm should employ a combined strategy of increasing satisfaction and switching barriers depending on product-market characteristics. To enhance customer retention in Bangkok, satisfaction towards destinations is the main driver for Thai tourists. In Bangkok, there are several categories of attractions, such as shopping centers, temples, museums and entertainment and recreation venues which lead to enhanced customer satisfaction. In this study, the majority of domestic tourist residences is in Bangkok. Hence, switching barriers is the most important determinant for customer retention in Pattaya. Time, money, and effort are all significant factors that determine switching barriers due to Pattaya's seaside attractions, the fact that it is located near Bangkok and the many routes to reach it.

Bangkok and Pattaya are the most popular destinations for Thai tourists. There are two significant managerial contributions in this study to comply with each destination. In Bangkok, satisfaction and switching barriers are the main drivers of customer retention. However, in Pattaya, switching barriers and trust are the main drivers of customer retention. This contribution is consistent with several studies indicating that each destination has different characteristics and needs to employ the appropriate combined strategy to retain customer loyalty.

\section{ACKNOWLEDGEMENTS}

This research is sponsored by Thammasat Business School, Thammasat University. 


\section{AUTHOR INFORMATION}

Assistant Professor Aurathai Lertwannawit received her Ph.D. in Marketing from Thammasat University in 2006. The interested research areas include Marketing, Hospitality and Tourism. She is a full-time lecturer in the Marketing Department, Thammasat Buinsess School, Thammasat University, Thailand.

E-mail:aurathai@tbs.tu.ac.th (Corresponding author)

Nak Gulid received his Ph.D. in Economics, International Trade and Finance as major areas from University of Missouri-Columbia, U.S.A. in 1994 and his Ph.D. in Marketing from Thammasat University in 2007, Thailand. His interested field area includes International Business, Marketing, Hospitality and Tourism, and Management. He is now the Director of MBA program at Srinakharinwirot University. E-mail: nakgulid@ gmail.com (preferred contact)

\section{REFERENCES}

1. Bansal, H. S. and Taylor, S. F. (1999). The Service Provider Switching Model (SPSM): A Model of Consumer Switching Behaviour in the Service Industry, Journal of Service Research, 2(2), 200-218.

2. $\quad$ Bender, A. (2012). The World's Top 10 Cities for Street Food, From http://www.forbes.com/pictures/ehlk45fiii/1-bangkok-thailand-3/

3. $\quad$ Berry, L. L. and Parasuraman, A. (1991). Marketing Services. New York: The Free Press.

4. Chadha, S. K. and Kapoor, D. (2009). Effect of Switching Cost, Service Quality and Customer Satisfaction on Customer Loyalty of Cellular Service Providers in Indian Market,The IUP Journal of Marketing Management, 8(1), 23-37.

5. Cronin, J. J., Brady, M. K. and Hult, G. T. M. (2000). 'Assessing the Effects of Quality, Value, and Customer Satisfaction on Consumer Behavioral Intentions in Service Environments', Journal of Retailing, 76(2), 193-218.

6. Cronin, J. J. and Taylor, S. A. (1992). 'Measuring Service Quality: A Re-Examination and Extension', Journal of Marketing, 56(3), 56-68.

7. Edward, M. and Sahadev, S. (2011). Role of Switching Costs in the Service Quality, Perceived Value, Customer Satisfaction and Customer Retention Linkage, Asia Pacific Journal of Marketing and Logistics, 23(3), 327-345.

8. Fornell, C., Ittner, C. D. and Larcker, D. F. (1995). 'Understanding and Using the American Customer Satisfaction Index (ACSI): Assessing the Financial Impact of Quality Initiatives', Paper Presented at IMPRO 95, Juran Institute's Conference on Managing for Total Quality.

9. Garbarino, E. and Johnson, M. S. (1999). 'The Different Roles of Satisfaction, Trust, and Commitment in Customer Relationships', Journal of Marketing, 63, 70-87.

10. Gerpott, T. J., Rams, W. and Schindler, A. (2001). 'Customer Retention, Loyalty, and Satisfaction in the German Mobile Cellular Telecommunications Market', Telecommunications Policy, 25(4), 249-269.

11. Geyskens, I., Steenkamp, J. E. M. and Kumar, N. (1998). 'Generalisations About Trust in Marketing Channel Relationships Using Meta-Analysis', International Journal of Research in Marketing, 15, 223248.

12. Gremler, D. D. and Brown, S. W. (1996). 'Service Loyalty: Its Nature, Importance, and Implications', In Edwardson, B., Brown, S. W. and Johnston, R. (Eds), Advancing Service Quality: A Global Perspective, International Service Quality Association, 171-180.

13. Gummesson, E. (1995). 'Relationship Marketing: Its Role in the Service Economy', In Glynn, W. and Barnes, J. G. (Eds), Understanding Services Management, Wiley, Chichester, 244-268.

14. Gundlach, G. T. and Murphy, E. P. (1993). 'Ethical and Legal Foundations of Relational Marketing Exchanges', Journal of Marketing, 57(October), 35-46.

15. Hair, J. F., Bush, P. R. and Oftinau, D. J. (2004). Marketing Research: Within a Changing Information Environment, (2nd edition). McGraw-Hill: New York.

16. Hart, C. W. and Johnson, M. D. (1999). Growing the Trust Relationship. Marketing Management, Spring, 8-19.

17. Heide, Jan B. and Allen M. Weiss (1995). 'Vendor Consideration and Switching Behavior for Buyers in High-Technology Markets', Journal of Marketing, 59(July), 30-43. 
18. Lee, J., Lee, J. and Feick, L. (2001). 'The Impact of Switching Costs on the Customer Satisfaction-Loyalty Link: Mobile Phone Service in France', Journal of Services Marketing, 15(1), 35-48.

19. Lee, M. and Cunningham, L. F. (2001). 'A Cost/Benefit Approach to Understanding Service Loyalty', Journal of Services Marketing, 15(2), 113-130.

20. Liang, C. J. and Wang, W. H. (2006), 'The Behavioral Sequence of the Financial Services Industry in Taiwan: Service Quality, Relationship Quality and Behavioral Loyalty', The Service Industries Journal, 26(2), 119-145.

21. Malhotra, N.K. (2004). Marketing Research: An Applied Orientation (Fourth Edition): International Edition, Fourth Edition, Prentice Hall Inc.

22. Morgan, R. M. and Hunt, S. D. (1994). The Commitment-Trust Theory of Relationship Marketing, Journal of Marketing, 58(3), 20.

23. Oliver, R. L. (1980). 'A Cognitive Model of the Antecedents and Consequences of Satisfaction Decisions', Journal of Marketing Research, 17(4), 460-469.

24. ------. (1981). Measurement and Evaluation of Satisfaction Processes in Retail Setting, Journal of Retailing, 57(3), 25-46.

25. Patterson, P. G., Johnson, L. W. and Spreng, R. A. (1997). Modeling the Determinants of Customer Satisfaction for Business-to-Business Professional Services, Journal of the Academy of Marketing Science, 25(1), 4-17.

26. Ranaweera, C. and Prabhu, J. (2003). 'The Influence of Satisfaction, Trust and Switching Barriers on Customer Retention in a Continuous Purchase Setting', International Journal of Service Industry Management, 14(4), 374-395.

27. Shy, O. (2002). 'A Quick-and-Easy Method for Estimating Switching Costs', International Journal of Industrial Organization, 20, 71-87.

28. Spekman, R. E. (1988). 'Strategic Supplier Selection: Understanding Long-Term Buyer Relationship', Business Horizons, (July/August), 75-81.

29. Szymanski, D. M. and Henard, D. H. (2001). 'Customer Satisfaction: A Meta-Analysis of the Empirical Evidence', Journal of the Academy of Marketing Science, 29, Winter, 16-35.

30. The Secretariat of the Cabinet, (2011). Policy Statement of The Council of Ministers, Bangkok, Thailand.

31. Urban, G. L., Sultan, F. and Qualls, W. J. (2000). Placing Trust at the Center of Your Internet

32. Strategy, Sloan Management Review, 42(Fall), 39-49.

33. Yi, Y. (1990). 'A Critical Review of Consumer Satisfaction', In Zeithaml, V. A. (Ed.), Review of Marketing, American Marketing Association, Chicago, IL, 68-123.

34. www.tourism.go.th 